\title{
The Role of Board of Directors in the Establishment of Risk Management Committee
}

\author{
Suhaimi Ishak ${ }^{1, *}$, Mohamad Naimi Mohamad Nor ${ }^{1}$ \\ ${ }^{1}$ Tunku Puteri Intan Safinaz School of Accountancy, Universiti Utara Malaysia, 06010, Sintok, kedah, \\ Malaysia
}

\begin{abstract}
The objective of the study is to discuss the roles of board of directors in the establishment of risk management committee for Malaysian's public listed companies. In Malaysia, based on the Malaysian Code on Corporate Governance (MCCG), $(2007 ; 2012)$ clearly stated the role and responsibility of the board of directors toward the risk management activities. At the Corporate Governance Week 2010 and 2011 as well, the chairman of the Security Commission Malaysia highlighted the responsibility of the board of directors in risk management processes and she expressed concern over the failure of the board of directors to establish appropriate measures for the risk management process in the company. The statement of the chairman of Security Commission Malaysia is in line with MCCG's best practices $(2000 ; 2007 ; 2012)$, i.e., the board of directors should identify principle risks and ensure the implementation of an appropriate system to manage these risks.
\end{abstract}

\section{Introduction}

This paper aims to discuss the concept and roles of board of directors (BOD) in the establishment of risk management committee (RMC) for Malaysian's public listed companies (PLCs). This study excluded the banking and finance companies due to this kind of industry have special and extra requirements by authorities especially on risk management practices. BOD is an integral part of every business organizations. They have a role for the future direction of the organization and company. In Malaysia, the regulators frequently ask for the BODs to have the strong position and role in corporate activities. They have another job portfolio that relating to the risk management. The establishment of $\mathrm{RMC}$ is one of the company initiatives in risk management practises [11] the formation of RMC is still voluntary in most countries in the world including Malaysia [9]. In Malaysia, based on the Malaysian Code on Corporate Governance [6, 7] clearly stated the role and responsibility of the BODs toward the risk management activities. The code highlighted for the BODs to have a system which effectively monitor and manage risks. This is an indicator of the importance of risk management and the oversight function of the BODs, even though there is no mandatory requirement for the establishment of the RMC. In June 2010, the chairman of the Security Commission Malaysia (SC) at its Corporate Governance

\footnotetext{
*Corresponding author: suhaimiishak@uum.edu.my
} 
Week 2010 together with Bursa Malaysia (BM), mentioned about the importance of proper risk management in a company. Tan Sri Zarinah Anwar reminded that poor risk management is a symptom of poor corporate governance practices. The chairman cautioned the BODs to fully and deeply understand the risks associated with the business operations, products and the market.

At international level, [2] introduced the Thought Leadership in ERM known as guideline for Understanding and Communicating Risk Appetite. This new guideline stresses the role of management and board oversight function in risk appetite activities for organisations; and the effectiveness of board oversight function is crucial. The Federation of European Accountants, Institute of Chartered Accountants Australia and the Centre for Audit Quality [4] jointly sponsored the roundtable discussion in New York City, Brussels and Hong Kong, where it was agreed that specific aspects of risk oversight responsibility should be allocated to a specific board committee, such as a RMC. The participants in that discussion also suggested for the establishment of a separate RMC that could focus on the consideration and identification of 'unknown risks, since the existing audit committee may be only familiar with the 'known risks'.

\section{Review of past literatures}

There are some previous studies that examined the BODs characteristics and the establishment of RMC but the samples limited to the financial year ended before the amendment of MCCG 2007 and 2012. Therefore, this study is expected to give knowledge and literature on how far the amendment of MCCG gives effect to the role and responsibility of BODs relating to risk management issues. Previous study such as [11] reveals that BODs with more independent willing to form or establish RMC. The researcher also argues that more independent BODs demonstrate good corporate governance. Meanwhile the result of study by [5] reveals the different result. The BODs independence is not significant to the establishment of RMC. This result supported the findings of [1] which there is no relationship between the BODs independence and the establishment of other BODs committee such as AC, remuneration and nominating committee. However, after the amendment of MCCG in [6] and [7], especially on risk management issues, the independent BODs is expected to be more aware on risk profile of the company.

Normally, the big size of BODs is easily to establish the other board sub-committee such as RMC since there are member with various skill and talent. This argument is supported by the study by [9] which larger BODs offer the resources to operate BODs committee. Further research also supported the findings whereby [5]) also find positive relationship between larger BODs and the establishment of RMC. Hence, larger BODs offer more experiences, skills and diversifications. The understanding on accounting and financial aspects is more crucial. BOD members with accounting and financial literate are more aware on activities related to financial and accounting performance [5] This argument is supported by [11] that BOD members with accounting and financial background have positive association to the establishment of RMC. They play active role in risk management activities.

Usually, BODs will discuss the matter pertaining to the company in BODs meeting. Frequent meeting encourage open discussion and improve communication among BODs members. Hence, the number of BODs meeting during the financial year is one of the initiatives by BODs itself. In term of risk management activities, [5] find no relationship between BODs meeting and the establishment of RMC. However, the earlier study by [11] finds positive relationship between BODs meeting and the establishment of RMC. Theoretically, if the BODs aware and diligent in discussing the risk issues, they intend to establish another board sub-committee to discuss more on the related issues such as the 
establishment of RMC. Multiple BODs is a common phenomenon in corporate world. More BOD members also become the BOD members in another companies at the same time even at different industry. This situation creates a broader range of knowledge, experiences and skills. The situation also brings them more sensitive and responsive to the company's issues including risk management. [3] argue multiple directorships tend to have motivation to involve in risk management activities. This argument also supported by [5] in the study that BODs outside directorships has positive and significant relationship between the voluntary establishments of RMC.

\section{Discussion and conclusion}

The increasing concern by the companies on risk management practices has reformed significant emphasis on the role of risk management. BODs as a key governance structure in an organization have a significant role for the implementation of risk management in a company. The establishment of RMC as a board committee is an example of the initiatives in risk management practices. This study intends to investigate which natures or features of BODs structures that established the RMC. Hence, the structure of BODs refers to the characteristics of BODs itself such as BODs independence, BODs size, BODs expertise, BODs diligence and BODs outside directorships. These characteristics are the indicators for effectiveness of BODs as a whole. This situation creates a motivation for the researcher to study on the relationship between the BODs characteristics and the establishment of RMC.

At the Corporate Governance Week 2010 and 2011 as well, the chairman of the SC highlighted the responsibility of the BODs in risk management processes. Tan Sri Zarinah Anwar expressed concern over the failure of the BODs to establish appropriate measures for the risk management process in the company. The statement of the chairman of $\mathrm{SC}$ is in line with MCCG's best practices [6, 7] i.e., the BODs should identify principle risks and ensure the implementation of an appropriate system to manage these risks. While the scholars of field such as $[9,10]$ suggested for future research to study the role and function of RMC, as well as its interaction in corporate governance mechanism. [11] convinced that the formation of RMC is a commitment of the company to improve the internal control environment and reduce the operational, financial and reputational risks. This area is still unexplored and the finding might contribute to new knowledge.

\section{References}

1. L. T. De Luca, Propulsion physics (EDP Sciences, Les Ulis, 2009) Carson, E. Factors associated with the development of board sub-committees. Corporate governance, 10(1), 4-18 (2002)

2. Committee of Sponsoring Organizations of the Treadway Commission. Enterprise risk management-understanding and communicating risk appetite. New York: COSO. (2012)

3. Fama, E. F., \& Jensen, M. C. Separation of ownership and control. Journal of Law and Economics, 26(2), 301-325 (1983)

4. Federation of European Accountants, Institute of Chartered Accountant Australia and Center for Audit Quality. Global observations on the role of audit committee, a roundtable discussion. New York, Brussels and Hong Kong: FEE. (2013)

5. Liew, C. L., Mat Zain, M., \& Jaffar, N. Board of directors and voluntary formation of risk management committee: Malaysia evidence. International Journal on Social Science Economics \& Art, 2(2), 67-73 (2012) 
6. Security Commission of Malaysia. Malaysian code on corporate governance (Revised 2007). Kuala Lumpur: Malayan Law Journal Sdn Bhd. (2007)

7. Security Commission of Malaysia. Malaysian code on corporate governance (Revised 2012). Kuala Lumpur: Malayan Law Journal Sdn Bhd. (2012)

8. Sekome, N. B., \& Lemma, T. T. Determinats of volunatry formation of risk management committees: evidence from an emerging economy. Managerial Auditing Journal, 29(7), 649-671. (2014)

9. Subramaniam, N., McManus, L., \& Zhang, J. Corporate governance, firm characteristics and risk management committee formation in Australian companies. Managerial Auditing Journal, 24(4), 316-339 (2009)

10. Yatim, P. Audit committee characteristics and risk management of Malaysian listed firms. Malaysian Accounting Review,8(1), 19-36 (2009)

11. Yatim, P. Board structure and the establishment of a risk management committee by Malaysian listed firms. Journal of Management \& Governance, 14(1), 17-36 (2010) 